\title{
SEJARAH KEMUNDURAN UMAT ISLAM
}

(Kajian Pemikiran Muhammad Umer Chapra

\section{dalam "The Future Of Economics; An Islamic Perspective”) \\ Oleh: Mukhlis Rahmanto \\ (Dosen UAD Yogyakarta)}

\begin{abstract}
Answering the question of why Muslims fall down suffering in many fields, including economics, is the work done by Chapra in this book. By using the model of the dynamics of socio-economic analysis of Ibn Khaldun, he began to read and trace the history of Muslims. Eventually he gained a few main factors causing the decline of Islam, namely: the movement of sufism which is not running on rails of origin, poor appreciation of the role of women, and declining quality of education. Deterioration occurs because of political authority $(\mathrm{G})$ negligent of its responsibilities, especially in upholding justice and Shariah, guarantee facilities to the people $(\mathrm{N})$, and realize their full potential. According to him, an urgent solutions must be implemented by Muslims are moving revival (resurrection) of Islam with one of its programs to critically analyze what is coming from the West to conform to the Islamic world view and values. The call to develop Islamic economics is just one strand of the Islamic revivalism movement.
\end{abstract}

Keywords: socio-economic dynamics, Sufism, women, education, despotism, revivalism

\section{A. PENDAHULUAN}

Terkait dengan kemunduran umat Islam, model dinamika sosio-ekonomi Ibnu Khaldun memungkinkan kita menjawab sebagian persoalan penting yang harus dijawab oleh ilmu ekonomi Islam. Persoalan-persoalan tentang mengapa 
dunia Islam bangkit begitu cepat dan terus maju selama beberapa abad dan sesudah itu bagaimana ia dapat merosot sedemikian rupa sehingga kehilangan elan vitalnya. Dan tidak saja sebagian besar menjadi daerah kolonialisme, melainkan juga tidak mampu memberikan respons yang baik terhadap tantangan yang dihadapinya.

Tidak mungkin menjawab pertanyaan-pertanyaan ini tanpa menelusuri ke belakang pada sejarah untuk melihat kapan, di mana, dan bagaimana kemerosotan bermula. Ini merupakan tugas berat. Namun jawabannya sangat krusial dan karena jika pertanyaan-pertanyaan ini tidak dijawab, tidak mungkin bagi ilmu ekonomi Islam melengkapi suatu strategi efektif untuk membalikan arah yang sudah terjadi beberapa abad dan menimpa di hampir seluruh bidang kehidupan, termasuk ekonomi.

B. BEBERAPA FAKTOR YANG MENYEBABKAN KEMUNDURAN UMAT ISLAM

\section{Peran Sufisme}

Konsekuensi lain dari korupsi dan tenggelamnya kalangan istana (pemerintah-kekhalifahan) terhadap kehidupan duniawi adalah dicarinya sejumlah ulama shalih di kalangan sufisme atau asketisme. Masalahnya, ajaran sufi tidak banyak memberikan perhatian pada kebaikan sosial dalam arti luas dengan memperjuangkan keadilan dan hak asasi manusia. Mereka berkonsentrasi pada keshalihan individu dalam bentuknya yang ekstrim. Bertentangan dengan tujuan syariah itu sendiri, yaitu menegakkan suatu tatanan sosio-ekonomi yang adil lewat promosi kebijakan individu dan masyarakat serta penciptaan institusi yang diperlukan untuk tujuan ini. Meski usaha merevitalisasinya telah dilakukan oleh semacam al-Ghazali (w.505/1111) dan Syaikh Ahmad Syirhindi (w.1034/1624), namun tetap belum mencukupi. 
Pemilihan dan pemihakan kekhalifahan pada ulama kalangan sufi ini menjauhkan ulama yang berkompeten dan berkedudukan tinggi yang mestinya dapat mengubah perjalanan sejarah dari realitas praktis dan dari perjuangan politik untuk menegakkan tatanan sosio-ekonomi yang adil. Maka di sini sufi jelas menjadi satu faktor yang membantu langgengnya kekuasaan yang tidak adil dan despotik. Sekalipun demikian kaum sufi masih dapat berperan penting dalam regenerasi moral kaum muslim jika mereka kembali pada misi asalnya, yaitu kesucian spritual, berpartisipasi dalam gerakan non-kekerasan dan damai untuk merestorasi keadilan dan hak-hak rakyat.

\section{Buruknya kedudukan wanita}

Dengan melemahnya pemerintahan pusat dan kemerosotan politik, posisi kedudukan wanita dalam berbagai sektor kehidupan pun alami kemerosotan. Padahal Al-Qur'an dan sabda Rasul telah menjamin kedudukan yang komplementer antara laki-laki dan perempuan wanita. Secara praktik kaum wanita banyak berperan pada masa Rasul dalam kegiatan-kegiatan keagamaan, sosial, pendidikan, ekonomi, dan politik. Berkebalikan dengan kondisi sekarang di mana wanita -di banyak negara yang mayoritasnya muslimdianggap terbelakang, buta huruf, dan dijauhkan hak-hak Islam yang sebetulnya melekat pada mereka. Pun fikih mengalami distorsi dengan menjustifikasi sadz al-dzarî'ah (menutup bahaya) untuk mencegah batasanbatasan yang sebenarnya diperbolehkan oleh syariah dalam kondisi normal. Kini sejumlah ulama mulai membela hak-hak kaum wanita ini dan mencoba memperlihatkan Islam yang sebenarnya dalam kasus ini.

\section{Kemerosotan dalam hal pendidikan}

Suatu pandangan dunia (worldview) yang menempatkan begitu pentingnya reformasi dan peningkatan sosio-ekonomi manusia tentu akan sangat mementingkan pendidikan. Bukankah ayat Al-Qur'an pertama yang turun mengajarkan manusia untuk belajar dan berpendidikan. Dengan 
pendidikanlah suatu landasan yang tepat dapat ditegakkan dan untuk pembinaan rakyat.

Sejarah Islam mencatat bagaimana masjid selain sebagai aktualita peribadatan juga digunakan untuk aktivitas pendidikan dan bagaimana pemerintah memback-up dan mendukung resmi seluruh aktivitas pendidikan hingga munculah akademi seperti bait al-hikmah dan perpustakaanperpustakaan umum di seluruh penjuru negeri Islam. Pun tidak ada dikotomi antara ilmu agama dan umum. Pengetahuan mulai dari fikih, botani, zoologi, hingga astronomi mendapat tempat dan pengembangan. $\mathrm{Di}$ sinilah pembangunan dan pendidikan mengalami saat-saat mesranya dalam sejarah Islam.

Masalah datang ketika subsidi dan dukungan penuh pemerintah itu merosot. Pemerintah mulai berpindah konsentrasi pada pembiayaan militer. Pendidikan mulai dibebankan pada pundak swasta seperti banyaknya wakaf yang dikelola untuk dijadikan lembaga ekonomi dan pendidikan. Masalah datang ketika pengelolaan wakaf itu diperuncing hanya untuk kegiatan keagamaan, lemahnya kaum swasta, dan kemerosotan ekonomi berdampak pada pendidikan dan pengembangan pengetahuan. Padahal banyak sektor kehidupan yang membutuhkan sumbangsih alumni yang berpendidikan. Sementara dunia Islam meredup, proses demokratisasi yang menjamin efektifitas penggunaan sumber daya untuk kepentingan publik mengalami kemajuan pesat di Barat. Dukungan-kerjasama pemerintah dan swasta menyebabkan kemajuan pengetahuan dan teknologi. Maka salah satu hikmah sejarah yang bisa kita ambil, bahwa demokrasi, pendidikan, dan pembangunan saling memperkuat satu sama lainnya.

\section{BEBERAPA PELAJARAN DARI SEJARAH KAUM MUSLIMIN}

Sejarah kaum muslimin memperlihatkan dengan jelas peranan komplementer antara rakyat $(\mathrm{N})$, syariah $(\mathrm{S})$, pemerintah $(\mathrm{G})$ kekayaan atau 
ekonomi (W), keadilan (J), dan pembangunan (G), dalam menentukan jatuh bangunnya suatu masyarakat atau peradaban. Kaum muslimin dalam periodisasi sejarahnya mampu mensinergikan semua unsur ini sehingga pembangunan dan kemajuan masyarakat cepat terwujud. Kemunduran terjadi karena otoritas politik $(G)$ lengah terhadap tanggungjawabnya terutama dalam menegakan keadilan dan syariah, menjamin fasilitas untuk rakyat $(\mathrm{N})$, dan mewujudkan potensi mereka secara penuh. Tidak hanya pembangunan yang mengalami kemunduran, kemiliteran pun mengalami hal yang sama. Masalah bertambah kompleks ketika kaum muslimin gagal mengambil pelajaran dari periodesasi sejarah mereka sendiri.

Maka beberapa pelajaran yang bisa kita ambil dari sejarah kita yaitu: Pertama, Tidak ada sinergi yang positif antara khalifah (pemerintah) dan majelis syura. Maka para penguasa cenderung lari dari tanggungjawabnya. Kedua, Keadaan pertama berlanjut pada penyakit-penyakit yang menggerogoti keadilan dan pembangunan. Korupsi, inefisiensi, despotisme, prioritas rendah pada pembangunan terutama pendidikan, riset, dan pembangunan infrastruktur, inflasi serta ketidakseimbangan fiskal, hingga kemunduran pengetahun dan teknologi berlangsung. Ketiga, Tidak mungkin bagi penguasa untuk memaksakan pandangan dunianya (worldview) pada rakyat seperti kasus inkuisisi pada zaman al-Makmun mengenai kemakhlukan al-Qur'an. Hal ini mengakibatkan hilangnya dukungan rakyat pada pemerintah. Keempat, Islam bukan penyebab kemerosotan, tapi manusia muslim itu sendirilah sebagai faktor utama terjadinya kemunduran.

\section{KEBANGKITAN MASA KINI; SEBUAH SURVEI}

Peradaban Barat terus berkembang dan mengambil alih obor pengetahuan dari dunia muslim. Semua pengetahuan mengalami kemajuan fenomenal termasuk pengetahuan sosial di mana ilmu ekonomi konvensional di dalamnya dan menjadi terpisah-independen sejak muncul Principles of 
Economics-nya Alfred Marshall pada tahun 1890. Tapi tidak semua kemajuan itu patut dipuji karena harus dibayar dengan ongkos sosial yang besar. Mulai dari kejahatan, perceraian, ketagihan obat-obatan, penyakit mental, dan bahkan institusi keluarga mengalami disiintegrasi juga solidaritas sosial yang melemah. Sayang sekali dunia Muslim buta dan banyak mengadopsi semua yang berbau Barat, terutama konsep materialisme dan sekulernya. Padahal sejarah mereka (muslim itu sendiri) telah mengilhami untuk mengadakan sterilisasi tehadap peradaban lain karena Islam mempunyai worldview tersendiri. Peran nilai moral dan ekonomi, institusi politik dan sosial yang saling berkaitan dalam alokasi dan distribusi sumber-sumber daya demi perwujudan tujuan sosial yang diinginkan di mana ditekankan oleh oleh Ibnu Khaldun dan para sarjana muslim lainnya diabaikan. Kasus tidak adanya filterisasi dan kritikan ini bisa dibaca pada pengajaran ilmu ekonomi di berbagai jenjang lembagai pendidikan di dunia muslim di mana isinya sama persis dengan apa yang diajarkan di Barat. Para pelajar lebih mengenal Adam Smith dan Keynes daripada Ibnu Sina atau Ibnu Rusyd. Buku History of Economic Analysis-nya Joseph Schumpeter ditelan mentah sebagai diktat kuliah. Padahal dalam buku Schumpeter tersebut telah terjadi penggelapan (blind spot) sejarah pemikiran ekonomi, yaitu dengan menghilangkan kontribusi muslim dalam periodisasi sejarah pemikiran ekonomi dunia tersebut.

Kini setelah kolonialisme berakhir, kebangkitan (revivalisme) Islam pun muncul. Kita perlu menganalisa secara kritis Barat agar sesuai dengan worldview dan Islamic values. Seruan mengembangkan ilmu ekonomi Islam hanyalah salah satu rangkaian dari revivalisme Islam dan itu dimulai dari konferensi internasional ilmu ekonomi Islam di Mekah tahun 1976. Maka munculah cendekiawan seperti Khursi Ahmad dan M. Nejatulah Siddiqie dan lembaga yang concern terhadap proyek ini seperti Center for Research in Islamic Economics pada King Abdul Aziz University. Namun penekanan yang 
lebih besar diberikan pada penjelasan apa bentuk ideal dari sistem ekonomi Islam, prinsip-prinsip operasionalnya, bagaimana membedakannya dari sosialisme dan kapitalisme, dan bagaimana hal itu dapat mewujudkan tujuan humanitarian Islam. Dan sekarang yang demikian sudah jelas.

\section{E. UANG, PERBANKAN, DAN KEBIJAKAN MONETER}

Tiga item masalah ini dalam ekonomi mempunyai penekanan mendalam baik dalam dataran teoritis maupun empiris. Sejumlah pembahasan telah dikerjakan dan salah satunya adalah pertanyaan terkait dengan makna dan signifikansi riba, mengapa dilarang, dan bagaimana hal itu dapat dihapuskan dari ekonomi, bagaimana upayanya, dan bagaimana uang dikelola dalam sebuah perekonomian Islam setelah penghapusannya. Perihal ini banyak kemajuan dialami dalam menjawab pertanyaan ini, meski belum memuaskan. Semua pertanyaan ini bersumber pada definisi riba di mana telah jelas hukumnya dalam Al-Qur'an dan Sunnah. Pun konsensus (ijma') ulama Muslim terdahulu hingga sekarang seperti terakhir pada Muktamar OKI, komite fikih Rabithah pada tahun 1985 dan 1986 di Kairo dan Mekah menyepakati akan keharamannya. Bahwa istilah riba mengandung unsur interest. Dewan Ideologi Pakistan menetapkan bahwa, "istilah riba mengandung arti bunga dalam segala manifestasinya dengan mengabaikan apakah bunga itu berkaitan dengan pinjaman untuk konsumsi atau untuk tujuan-tujuan produktif, apakah pinjaman itu bersifat personal atau komersial, apakah peminjam itu lembaga pemerintahan, invidu swasta atau perusahaan, dan apakah suku bunga itu rendah atau tinggi."

Akan tapi perbedaan-perbedaan seputar ini tetap akan terjadi dan bahkan akan mendapatkan momentum sampai kaum muslimin mampu mendirikan alternatif yang baik atau sistem keuangan Barat yang berlaku menghadapi kasus yang serius (seperti krisis keuangan global tahun 2008 ini, pen.). Kasus yang kedua meningkatnya dukungan bahkan di dunia Barat dengan makin 
meningkatnya penggunaan penyertaan modal (equity) dan berkurangnya (pembiayaan lewat) kredit terutama yang berjangka pendek, untuk membiayai proyek-proyek jangka panjang dan spekulasi. Munculnya krisis demi krisis yang melanda keuangan Internasional akan memperlebar momentum untuk kebangkitan Islam. Dan perbankan Islam akan mengalami kemajuan di dunia Muslim.

\section{F. KESIMPULAN}

Tampaknya kaum muslimin telah gagal mengambil pelajaran dari sejarah mereka sendiri. Usaha yang harus cepat dilakukan adalah menghapus kemerosotan-kemerosotan ini. Penghapusan legitimasi politik tidak akan menyelesaikan masalah. Masih diperlukan jaminan untuk menegakan pertanggungjawaban reformasi institusional, dan penggunaan sumber-sumber daya publik untuk pendidikan secara lebih efektif, peningkatan moral dan materiil, pembangunan infrastruktur dan kemashlahatan umum yang lain. Di samping itu korupsi juga harus dikubur dan belanja pertahanan dikurangi. Pemerintah dapat dipaksa untuk memilih kebijakan-kebijakan hidup berdampingan secara damai dan mengurangi konflik dan konfrontasi baik internal maupun eksternal. Sayang sekali ini belum terjadi. Revivalisme Islam dengan satu gerakan utamanya membangkitkan ilmu ekonomi Islam masih harus diusung dan dibumikan meski melalui batu terjal hambatan yang harus dilaluinya. 


\section{DAFTAR PUSTAKA}

Chapra, Muhammad Umer, 2001, Masa Depan Ilmu Ekonomi; Sebuah Tinjaun Islam, Cet. 1, Jakarta, Gema Insani Press bekerjasama dengan Tazkia Cendikia

Mannan, M. Abdul, 1997, Teori dan Praktek Ekonomi Islam (Islamic Economic Theory and Practice), Yogyakarta: PT. Dana Bhakti Primayasa

An-Nabhani, Taqyuddin. (2002) Membangun Sistem Ekonomi Alternatif Perspekrif Islam, Surabaya: Risalah Gusti

Naqvi, Haider. (2003) Menggagas Ilmu Ekonomi Islam, Yogyakarta: Pustaka Pelajar. 